\title{
VIOLÊNCIA, PODER, LEI E JUSTIÇA, SEGUNDO WALTER BENJAMIN, JACQUES DERRIDA E SLAVOJ ZIZEK E CONEXÕES COM A EDUCAÇÃO
}

Hildemar Luiz Rech ${ }^{1}$

\begin{abstract}
RESUMO
Para Walter Benjamin há um entrelaçamento entre as violências instauradora e mantenedora do direito. Somente a violência divina, como meio puro e imediato, pode suspender e aniquilar o direito e a violência mítica. Por fim, no que se refere à educação como emancipação, Benjamin entende que esta implica a suspensão do tempo linear e vazio e a convocação do tempo intensivo e surpreendente do Agora. Já para Derrida a justiça está para além da lei, transcendendo-a. O direito é finito, contingente e historicamente determinado. Já a justiça é infinita e absoluta. Apenas a desconstrução, seguida pela reconstrução, pode mover o direito - apesar da distância intransponível - para o espírito da justiça. Por fim, para Derrida, a educação na concretude é falha, mas, para se manter na trilha do reconhecimento da liberdade e da singularidade, ela deve aceitar a diferença do outro e assumir a tarefa da desconstrução-reconstrução. Já, para Zizek, a idéia de uma forma vazia da lei, para além de suas encarnações positivas, remete à sua afirmação como inconsciente e como indício de um conteúdo recalcado. Já a violência apresenta, para Zizek, três dimensões: a simbólica, a objetiva (ou sistêmica) e a subjetiva. Quanto à educação, cabe reinventá-la radicalmente, pois a privatização do conhecimento intelectual e também da automação e digitalização sócio-econômica, de acordo com as regras do mercado capitalista, puseram a educação em grave crise.
\end{abstract}

Palavras-chave: Poder. Violência. Direito. Justiça. Educação.

\section{VIOLENCE, POWER, LAW AND JUSTICE, ACCORDING WALTER BENJAMIN, JACQUES DERRIDA AND SLAVOJ ZIZEK AND CONNECTIONS WITH EDUCATION}

\begin{abstract}
For Walter Benjamin, there is an interlacement between the violence that establishes the law and the violence as the maintainer of law. Only a divine violence, with its pure and immediate means, can suspend and annihilate the law and the mythical violence. About the education as emancipation, Benjamin assumes that it implicates a suspension of the linear and empty time, and a calling up of the intensive and surprising time of the Jetztzeit. On his time, Derrida points out that the justice is always beyond the law, it transcends it. The law is finite, contingent and, at one historical viewpoint, determined. On the other hand, the justice is infinite and

Doutor em Ciências Sociais pelo IFCH da UNICAMP, SP, e pela Universidade de Manchester, Inglaterra; Professor Associado IV e Pesquisador no Departamento de Fundamentos da Educação; e no Programa de Pós-Graduação em Educação, na Linha de Pesquisa de Filosofia e Sociologia da Educação - pelo eixo Marxismo, Teoria Crítica e Filosofia da Educação -, FACED-UFC, Fortaleza, CE. E-mail: hluizrech@gmail.com
\end{abstract}


absolute. Only a dis-construction, followed by a re-construction can move the law - in spite of the insurmountable distance - to the mind of justice. Moreover, Derrida claims that education, in its reality, always presents failures, but, in order to maintain itself in the path of human recognition of freedom and singularity, education needs to accept the difference of the other and embrace the mission of deconstructionreconstruction. On the other hand, Zizek considers that the idea of one empty form of law, beyond its positive incarnations, refers to its affirmation as unconscious and as a sign of repressed contents. According to yet Zizek, the violence presents three dimensions: a symbolic one; an objective one; and a subjective one. Regarding to education, it is necessary to reinvent it radically, since the privatization of intellectual knowledge, as the privatization of the socio-economic automation and digitalization, according the market rules, has put education in a serious crisis.

Key-words: Power. Violence. Law. Justice. Education.

O presente artigo consiste em alguns apontamentos sobre as leituras que três autores, Walter Benjamin, Jacques Derrida e Slavoj Zizek, fazem sobre os conceitos de poder, lei, direito, violência e justiça. Na parte conclusiva do texto são, ademais, tecidas algumas conexões entre o pensamento destes autores e a educação.

\section{Apontamentos da abordagem de Walter Benjamin sobre o poder, a lei, o direito e a violência}

Em seu texto "Para uma crítica da Violência", Walter Benjamin emite a convicção de que a fundação do direito (Recht) insere-se dentro da própria fundação do poder (Macht). Segundo o autor, a violência (Gewalt), presente na instauração e na manutenção do direito, é justificada como um meio inarredável não apenas para a fundação, mas também para a legitimação e a aplicação do direito, no cerne da estrutura do poder. Assim, pois, o direito e o poder jamais abdicam da violência como ameaça latente permanente. Ou seja, a própria fundação do direito constitui a violência como sua força instauradora e, mesmo no exercício de sua aplicação e manutenção, o direito jamais abdica da violência. Portanto, o direito está imbricado com um fim necessário sob o nome de Poder que é visceralmente entrelaçado com a própria violência. Enfim, desse modo, a instauração do direito é instauração do poder e, enquanto tal, um ato de manifestação imediata da violência.

Portanto, de acordo com a perspectiva benjaminiana, o poder é o princípio de toda instauração mítica do direito e como tal se situa a contrapelo da justiça que é o princípio de toda instauração divina de finalidade. A violência divina é revolucionária e se opõe à violência mítica, pois, sendo esta última tanto instauradora quanto 
mantenedora do direito, a violência divina depõe, aniquila, destrói e ultrapassa o direito.

Além disso, cabe observar que a violência mítica - enquanto instauradora e mantenedora do direito - é repressiva, brutal, sangrenta e ameaçadora, trazendo, simultaneamente, culpa e expiação; por outro lado, a violência divina,que expia a culpa, é fulminante e é letal de maneira não sangrenta. Benjamin, portanto, acredita na possibilidade de uma violência divina pura fora do direito e não reconhecida como proveniente de uma decisão da vontade soberana do poder, mas originária de uma ação humana inteiramente anônima.

Sob este aspecto, tomando a violência divina como foco analítico cabe enfatizar que esta apresenta uma forte afinidade eletiva com 0 ato revolucionário que rompe com o status quo, enfim de ruptura com o estado de exceção do poder soberano. A propósito, a violência divina benjaminiana - que emerge como uma espécie de repetição redentora de todas as tentativas fracassadas de emancipação do passado - se encontra atravessada visceralmente por uma determinada idéia de justiça, sem mediações com o poder constituído. Nesta perspectiva, apanhar a Revolução soviética de outubro de 1917, no seu devir, significa discernir o imenso potencial de emancipação que se libertou com aquele evento e que, ao mesmo tempo, se quebrou durante a sua efetivação histórica.

Portanto, sob este prisma é que Benjamin instaura a noção de que uma intervenção revolucionária sempre atualiza, repete e redime as tentativas fracassadas no passado, de busca da liberdade e da justiça coletiva e social. Nestes termos, tal intervenção também busca suspender a força opressora, de marginalização e de anti-solidariedade impregnada no tecido social, se posicionando, desse modo, frontalmente contra o predomínio arbitrário das forças econômicas do capital e com intensidade contra toda ação unilateral, arbitrária, autoritária ou totalitária do poder soberano estatal.

Por outro lado, ainda referente às duas formas de violência - a instauradora e a mantenedora do direito - cabe observar que elas, conforme Benjamin (2011), não são completamente distintas e nem radicalmente exclusivas uma da outra. Pois, a violência fundadora é seguidamente representada e necessariamente repetida pela violência conservadora, que mantém e assegura a permanência e a aplicabilidade do direito. 
Para Benjamin (2011), a crítica da violência só pode ser feita na ordem simbólica da lei, da política e da moral e não no quadro das contingências das forças da natureza. Assim, à tese do direito natural, que vê a violência como dada pela natureza, contrapõe-se diametralmente a do direito positivo, a da violência como produto do devir histórico. A propósito, conforme Benjamin:

\begin{abstract}
[Desse modo,] se o direito natural pode julgar cada direito existente apenas por meio da crítica aos seus fins, o direito positivo, por sua vez, pode avaliar qualquer direito apenas pela crítica aos seus meios. (...). [Ou seja,] o direito natural almeja 'justificar' os meios pela justiça dos fins, o direito positivo, 'garantir' a justiça dos fins pela 'justificação' dos meios. A antinomia se mostraria insolúvel se o pressuposto dogmático comum fosse falso; se, por um lado, meios justificados, e, por outro, fins justos, se mostrassem em um conflito inconciliável. ${ }^{2}$
\end{abstract}

Portanto, segundo o filósofo berlinense, a única possibilidade de superação do jus naturalismo e do direito positivo é a filosofia da história. Pois, para Benjamin, somente ela pode ajudar a esclarecer a imbricação entre as duas dimensões de violência inerentes ao direito, quais sejam: a violência instauradora do direito (rechtsetzende Gewalt) e a violência mantenedora do direito (rechtserhaltende Gewalt). A propósito, segundo Benjamin, tanto do ponto de vista do direito natural(que defende o uso de meios violentos, para a obtenção de fins justos), quantona perspectiva do direito positivo(quejulga o direito pela legitimidade dos meios, ao invés de justificar os meios pelos fins) impõe-se uma adequação entre meios e fins.

Sob este prisma, para Benjamin, como observa Seligmann-Silva:

[É preciso] deixar em suspenso a determinação da justiça e voltar-se para a questão da legitimidade dos meios. (...). A análise dos fins do poder não é suficiente para avaliá-lo: precisamos abordar o poder em sua origem histórica. Isto remete em Benjamin não apenas a uma genealogia (nietzschiana) das leis (dos mores), mas à sua "origem histórica" (...). Neste ponto de sua argumentação (...) [o mesmo autor] já representa uma aparição de um "estado de exceção" dentro da aparente normalidade do estado de direito (...). O poder jurídico identifica neste desafio uma ameaça. E hoje sabemos até que ponto este sentir-se ameaçado (ou melhor, este apresentar-se como ameaçado) pode levar os detentores do poder a utilizar uma carga de violência inimaginável. ${ }^{3}$

Assim, a mesma ambiguidade do Poder que é detectada com a punição via pena de morte também é detectada na instituição estatal que é a polícia que funciona como "poder mantenedor e instituidor do direito". Nestes termos, a

2 BENJAMIN, 2011, p. 124.

3 SELIGMANN-SILVA, 2005; p. 2-3. 
ambiguidade do poder se coloca pelo fato de a polícia ser simultaneamente um órgão de poder do sistema jurídico e pelo fato de seus próprios fins jurídicos serem estabelecidos por decretos. Por isso não é possível criticar o poder sem criticar a ambiguidade do direito. Como destaca Seligmann-Silva:

A polícia funciona como um instrumento do Estado que intervém onde o
sistema jurídico esbarra no seu limite. Alegando "questões de segurança", o
Estado pode assim controlar seus cidadãos. Benjamin fala de uma "vida
regulamentada por decretos" (algo próximo do que veremos mais adiante,
quando observamos o que ele escreveu sobre a normalidade do Estado de
Exceção). A polícia aparece como um poder gestaltlos, amorfo, em
comparação com o direito que ainda fazia referência a uma decisão
[entscheidung], que valia como uma categoria metafísica que a abria à
crítica.

Por outro lado, a violência policial, segundo Benjamin (2011), é instauradora do direito - pois sua função característica, sem dúvida, não é a promulgação de leis, mas a emissão de decretos de todo tipo, que ela afirma como pretensão de direito e é também mantenedora do direito, uma vez que se coloca à disposição de tais fins. Enfim, para Benjamin:

A afirmação de que os fins da violência policial seriam sempre idênticos aos do resto do direito, ou pelo menos teriam relações com estes, é inteiramente falsa. Pelo contrário, o 'direito' da polícia assinala o ponto em que o Estado, seja por impotência, seja devido às conexões imanentes a qualquer ordem do direito, não consegue mais garantir, por meio dessa ordem, os fins empíricos que ele deseja alcançar a qualquer preço. Por isso, a polícia intervém "por razões de segurança" em um número incontável de casos nos quais não há nenhuma situação de direito clara; para não falar nos casos em que, sem qualquer relação com fins de direito, ela acompanha o cidadão como uma presença que molesta brutalmente ao longo de uma vida regulamentada por decretos, ou pura e simplesmente o vigia. Ao contrário do direito, que reconhece na "decisão" fixada no espaço e no tempo uma categoria metafísica que lhe permite ser objeto de avaliação crítica, a consideração da instituição policial não encontra nada de essencial. Sua violência não tem figura, assim como não tem figura sua aparição espectral, jamais tangível, que permeia toda a vida dos Estados civilizados. ${ }^{5}$

Desse modo, para Benjamin, na própria instauração e também na conservação da lei insere-se algo que está fora da lei, como um real da violência que coincide com a própria existência da lei. Nesta perspectiva, especialmente a polícia representa uma espécie de mistura espectral de duas formas de violência (a instauradora e a mantenedora). Ou seja, a polícia é o lugar em que a violência

\footnotetext{
4 SELIGMANN-SILVA, 2005; p.5.
}

5 BENJAMIN, 2011, p.135-136. 
extralegal, da qual depende estruturalmente o preceito legal, manifesta-se da maneira mais clara.

Sob outro ângulo, Benjamin ainda observa o seguinte:

\begin{abstract}
A violência que mantém o direito é uma violência que ameaça. Só que essa ameaça não deve ser interpretada no sentido de intimidação, como fazem teóricos liberais mal instruídos. Uma intimidação, no sentido preciso da palavra, exigiria uma determinação que contradiz a essência da ameaça e que também não pode ser obtida per nenhuma lei, pois persiste a esperança de escapar a seu braço. A lei se mostra, assim, tão ameaçadora como o destino, do qual depende se o criminoso cairá ou não sob seu jugo. O sentido mais profundo da indeterminação da ameaça do direito se revelará tão só pela consideração posterior da esfera do destino, da qual esta, a ameaça, se origina. Um indício precioso dessa indeterminação se encontra no domínio das penas. (...) [Assim, por exemplo,] uma contestação da pena de morte não se dirige contra uma medida punitiva, nem contra algumas leis, mas contra 0 próprio direito na sua origem. Se, de fato, a violência [Gewalt] coroada pelo destino, for a origem do direito, pode-se, então, prontamente supor que no poder [Gewalt] supremo, o poder sobre a vida e a morte, quando este adentra a ordem do direito, as origens dessa ordem se destacam de maneira representativa no existente e nele se manifestam de forma terrível. Em consonância com isto, está o fato de que a pena de morte, em condições primitivas de direito, é decretada até mesmo para delitos como crimes contra a propriedade, em relação aos quais parece inteiramente "desproporcional". Pois seu sentido não é o de punir a infração do direito, mas o de instaurar o novo direito. Com efeito, mais do que em qualquer outro ato de cumprimento do direito, no exercício do poder sobre a vida e a morte é a si mesmo que o direito fortalece. Mas é precisamente aí que, ao mesmo tempo, se anuncia também algo de podre no direito, que uma sensibilidade apurada percebe com mais acuidade. ${ }^{6}$
\end{abstract}

Frente ao caráter violento do direito e das leis de qualquer Estado moderno, Benjamin, então, defende a violência como meio puro, ou seja, como "violência divina", que suspende a lei opressora sobre o povo; que assegura a existência da vida fora do direito estatal; e que rompe com o contínuo da história, aniquilando-se assim a textura da história prévia que é a dos vencedores e que está impregnada de barbárie.

Nestes termos cabe aqui uma reflexão sobre a ambigüidade da relação simbiótica do direito com o poder, ainda mais em um contexto da "maior degenerescência inimaginável do poder" (Benjamin, apud Seligmann-Silva, 2005, p.06).

Para Benjamin (2011), diante da identificação do sistema jurídico com o poder mítico, cabe a sua aniquilação para que se barre a força da reprodução mítica do poder. Assim, trata-se de abrir espaço para um poder puro e imediato, enfim, divino,

\footnotetext{
6 BENJAMIN, 2011, p.133.
} 
que comum golpe letal, mas não sangrento, aniquile o direito ambíguo atrelado ao poder mítico.

Portanto, segundo Benjamin (2011), justiça e direito são excludentes, porque o direito está imbricado com o poder amparado na violência mítica, ou seja, a própria institucionalização do poder, como um ato de manifestação imediata da violência, implica a institucionalização mítica do direito. A justiça, por outro lado, é divina e, como tal, é o princípio de toda instituição divina de fins, que emana do povo.

Enfim, o poder mítico, que implica a institucionalização mítica do direito, "é poder sangrento sobre a vida, sendo esse poder o próprio fim deste direito; ao passo que o poder divino é um poder puro sobre a vida toda, sendo a vida o seu fim" (Benjamin, apud Callado (2012, p.89)).

Nesta mesma linha de análise, Callado aborda a relação entre poder e mito e entre direito e violência, no quadro da degenerescência política na República de Weimar, antes da ascensão do nazismo na Alemanha:

\begin{abstract}
A degradação que vitimou o sistema legislativo de Weimar só poderia ser explicada em suas raízes míticas. Portanto, o foco da análise sobre o poder derivado do mito deve repousar sobre a relação do direito com a violência. A análise de Benjamin sobre a decadência dessa instituição incide no trânsito entre meios e fins, que nem o direito natural nem o direito positivo conseguem contornar. Isso leva Benjamin a decidir-se por uma análise à luz da filosofia da história. ${ }^{7}$
\end{abstract}

Desse modo, um dos pontos de originalidade na abordagem de Benjamin consiste em evidenciar que a institucionalização do poder reproduz, desde seu ponto de partida, um enroscamento inexorável com a violência mítica. Segundo o autor, também o direito, voltado para a conservação mítica do poder, está comprometido com essa violência mítica, na contramão da justiça.

\title{
Reflexões de Jacques Derrida sobre a força da lei, o poder, a justiça e a violência
}

A segunda abordagem sobre a relação entre poder, direito, violência e justiça aqui considerada é a de Jacques Derrida (2010). Para este autor a justiça está para além da lei. Como esta última é o produto da dinâmica social e política do poder, ela é finita, relativa, contingente e historicamente determinada. Já a justiça transcende a esfera da negociação, do arranjo social e da deliberação política, o que a torna infinita e absoluta. Porém, a crítica da violência só pode ser feita no bojo da ordem

7 CALLADO, 2012, p.85. 
simbólica da lei, da política e da moral e não no quadro das contingências das forças da natureza.

Por conseguinte, Derrida apresenta o entendimento de que direito e justiça são conceitos distintos que devem permanecer separados. Ademais, o mesmo autor detecta que com a aplicação da lei surge um problema que consiste na dificuldade de distinguir entre a aplicabilidade legítima da lei e a violência nela implicada, a qual é vista como injusta. $E$, nestes termos, o autor se pergunta sobre como funciona ou poderia funcionar uma força justa ou não violenta a acompanhar a aplicação legítima da lei.

Ademais, conforme Derrida (2010), a justiça na forma do direito ou da lei não é dependente, de modo direto e causal, de um poder social ou político-ideológico visualizado como existindo fora e antes dela, e ao qual a justiça na forma do direito se submeteria ou adequaria, segundo a utilidade. Segundo Derrida (2010, p.6): "[Da lei] é difícil dizer se 'ela' é uma conveniência, uma polidez, a lei do mais forte ou a lei equitativa da democracia. E se ela pertence à justiça ou ao direito" (Derrida, 2010, p.6).

Entretanto, não há lei sem aplicabilidade e esta não se efetiva sem a força, "(...) quer essa força seja direta ou não, física ou simbólica, exterior ou interior, brutal ou sutilmente discursiva - hermenêutica -, coercitiva ou reguladora" (Derrida, 2010, p.9).

Ademais, o próprio direito não se sustenta - e sequer é possível de ser conceituado - sem a presença da força. Ou seja, a aplicabilidade do direito não vem de fora, para ajuntar-se de modo complementar ao direito, o que significa que "não há direito que não implique nele mesmo, a priori, na estrutura analítica de seu conceito, a possibilidade de ser "enforced", aplicado pela força" (Derrida, 2010, p.8).

Neste quadro impõe-se, de certo modo, uma ambivalência incontornável entre a "força da lei" enquanto julgada legítima e a violência considerada injusta. O termo alemão "Gewalt", de certo modo, enfeixa esta dubiedade, pois pode ao mesmo tempo significar o poder legítimo, a autoridade justificada e a força pública e, por outro lado, a violência pretensamente originária que é injustificável por si mesma. Ou seja, o próprio poder legítimo não podia autorizar-se por nenhuma legitimidade anterior, de modo que precisou, devido ao seu estado inicial, nem legal e nem ilegal, instaurar, mediante dispositivos coercitivos, essa autoridade como força de lei de um poder legítimo. 
Já no período pré-socrático, Heráclito definiu que o direito, o julgamento, a pena, enfim, a justiça (díke), é originariamente a disputa (streit), a discórdia ou a luta (kampf), "(...) isto é, também adikía, a injustiça" (Heidegger, apud Derrida, 2010, p.10).

Segundo Derrida, a partir de uma leitura desconstrucionista, o recurso à palavra "força" é frequente e decisivo em lugares estratégicos, mas sempre acompanhado de um alerta, na medida em que implica "(...) o risco de uma autorização concedida à força violenta, injusta, sem regra, arbitrária" (Derrida, 2010, p.11).

Contra os riscos irracionalistas, segundo o autor, cabe sempre tomar a precaução de lembrar o caráter diferencial da força. Ou seja, como explicita Derrida:

\begin{abstract}
Trata-se sempre da força diferencial, da diferença como diferença de força, da força como différance ou força de différance (a différance é uma força diferida-diferente); trata-se sempre da relação entre a força e a forma, entre a força e a significação; trata-se sempre da força "performativa", força ilocucionária ou perlocutória, força persuasiva e de retórica, de afirmação da assinatura, mas também e, sobretudo, de todas as situações paradoxais em que a maior força e a maior fraqueza permutam-se estranhamente. O mesmo acontece, aliás, com a palavra "justiça". ${ }^{8}$
\end{abstract}

A justiça nas mãos da lei é reduzida à simples imposição da lei. A aplicabilidade ou a imposição da lei é a força implícita no conceito mesmo da justiça como direito. A propósito: "A palavra imposição lembra-nos que não existe coisa tal como uma lei (direito) que não implique em si mesma, a priori, a estrutura analítica do seu conceito, a possibilidade de ser 'imposta', aplicada pela força" (Derrida, 2004, p.172).

O problema da justiça só pode ser endereçado de modo oblíquo - mediante a desconstrução deste conceito. Pois, "(...) não se pode falar diretamente da justiça, tematizar ou objetivar a justiça, dizer 'isto é justo' e, ainda menos, 'eu sou justo', sem trair imediatamente a justiça, senão o direito" (Galilée, apud, Derrida, 2010, p.17).

Embora a justiça não seja necessariamente o direito ou a lei, ela só pode tornar-se justiça em direito quando detém a força desde seu primeiro instante, sua palavra inicial. Como exprime Derrida:

No começo da justiça terá havido o logos, a linguagem ou a língua, mas isso não é necessariamente contraditório com outro incipit que dissesse: 'No

${ }^{8}$ DERRIDA, 2010, p.11. 
começo, terá havido a força'. O que se deve pensar é, pois, esse exercício da força na própria linguagem, no mais íntimo de sua essência, como no movimento pelo qual ela se desarmaria absolutamente por si mesma. ${ }^{9}$

Derrida cita Pascal: "A justiça sem a força é impotente [...]; a força sem a justiça é tirânica. A justiça sem força é contradita, porque sempre há homens maus; a força sem a justiça é acusada. É preciso, pois, colocar juntas a justiça e a força (...)" (Pascal, apud Derrida, 2010, p.19).

Ou seja, segundo Derrida (2010), uma justiça exige o recurso à força, ela não é feita se ela não tiver a força para ser imposta, 'enforced', pois, uma justiça impotente não é uma justiça, no sentido do direito. De modo que, a necessidade da força está implicada no justo da justiça.

Ademais, Derrida cita e comenta Montaigne, onde este aponta para o "fundamento místico" da autoridade das leis: "Ora, as leis se mantêm em crédito, não porque elas são justas, mas porque são leis. É o fundamento místico de sua autoridade, elas não têm outro [...]. Quem a elas obedece porque são justas não Ihes obedece justamente pelo que deve" (Montaigne, apud Derrida, 2010, p.21).

A propósito, segundo Derrida (2010), Montaigne entende que obedecemos às leis porque elas têm autoridade. $\mathrm{E}$ 'a autoridade das leis repousa apenas no crédito que Ihes concedemos', o que também justifica e alude ao caráter 'místico' da autoridade. Enfim, este ato de fé é o único fundamento da autoridade que, porém, não é racional, mas 'decorrente da fantasia fundamental', ou seja, da crença dos indivíduos na autoridade das leis.

Desse modo, apresenta-se uma distinção entre o direito e a justiça, pois para Montaigne as leis nãosão justas em si como leis. Isto significa que a justiça como direito não é a justiça, porque as leis naturais estão sempre sujeitas ao pecado original da corrupção, o que demanda o suplemento do direito histórico ou positivo, isto é um acréscimo de ficção legítima. Enfim, “(...) nosso direito tem ficções legítimas sobre as quais ele funda a verdade de sua justiça" (Montaigne, apud Derrida, 2010, p.22).

Além disso, Derrida retoma a crítica pascaliana no ponto em que esta, em seu princípio, 'remete ao pecado original e à corrupção das leis naturais por uma razão ela mesma corrompida': "Há, sem dúvida, leis naturais; mas esta bela razão

9 DERRIDA, 2010, p.17-18. 
corrompida corrompeu tudo" (Pascal, apud Derrida, 2010, p.23). E em outra parte: "Nossa justiça [se anula] diante da justiça divina" (Pascal, apud Derrida, 2010, p.23).

Segundo Derrida (2010), estes insights de Montaigne e de Pascal nos preparam para a leitura de Benjamin sobre o poder e a violência. A propósito, cabe aqui realçar a distinção que este faz entre a instauração mítica do direito, com sua violência mítica sangrenta e ameaçadora, e a justiça, que, segundo Benjamin (2011), é o princípio de toda instauração divina de finalidade. Ademais, cabe aqui enfatizar que, nos termos de Benjamin (2011), a violência divina é revolucionária e se opõe à violência mítica, pois, sendo esta última, tanto instauradora quanto mantenedora do direito, a violência divina depõe, aniquila, destrói e ultrapassa o direito.

Nestes termos, segundo Derrida, os pensamentos críticos de Pascal e Montaigne estabelecem "(...) as premissas de uma filosofia crítica moderna, ou uma crítica da ideologia jurídica, [enfim], uma dessedimentação das superestruturas do direito que ocultam e refletem, ao mesmo tempo, os interesses econômicos e políticos das forças dominantes da sociedade" (Derrida, 2010, p.23).

Todavia, logo em seguida, Derrida, retoma o núcleo decisivo de sua abordagem, que o leva a relativizar no pensamento pascaliano a idéia do direito como um mecanismo simplesmente a serviço de um poder social, seja este econômico, político ou ideológico na sociedade. De modo que para além de seu princípio e de sua alçada, este pensamento, segundo Derrida (2010, p.23-24) "(...) concerne talvez a uma estrutura mais intrínseca. Uma crítica da ideologia jurídica não deveria jamais negligenciá-la".

Ademais, conforme Derrida:

O próprio surgimento da justiça e do direito [em Pascal] - o momento instituidor, fundador e justificante do direito - implica uma força performativa, isto é, sempre uma força interpretadora e um apelo à crença. (...) No sentido de que [este surgimento] manteria, com aquilo que chamamos de força, poder ou violência, uma relação mais interna e mais complexa (...). O momento de fundação [da justiça] ou mesmo de instituição jamais é, aliás, um momento inscrito no tecido homogêneo de uma história, pois ele o rasga por uma decisão. Ora, a operação de fundar, inaugurar, justificar o direito, fazer a lei, consistiria num golpe de força, numa violência performativa e, portanto, interpretativa que, nela mesma, não é nem justa nem injusta, e que nenhuma justiça, nenhum direito prévio e anteriormente fundador, nenhuma fundação pré-existente, por definição, poderia nem garantir nem contradizer ou invalidar. Nenhum discurso justificador pode, nem deve assegurar o papel de metalinguagem com relação à 
performatividade da linguagem instituinte ou à sua interpretação dominante. O discurso encontra ali seu limite: nele mesmo, em seu próprio poder performativo. É o que proponho aqui chamar, deslocando um pouco e generalizando a estrutura, o místico. Há ali um silêncio murado na estrutura violenta do ato fundador. Murado, emparedado, porque esse silêncio não é exterior à linguagem. Eis em que sentido eu seria tentado a interpretar, para além do simples comentário, o que Montaigne e Pascal chamam de fundamento místico da autoridade. ${ }^{10}$

Sob esta perspectiva, a origem da autoridade e a fundação da lei somente podem apoiar-se sobre elas mesmas, na medida em que elas, sem ser legais ou ilegais em seu momento fundador, são uma violência sem fundamento.

Segundo o filósofo da desconstrução, as leis, em seu momento fundador, aparecem sempre entrelaçadas com uma violência coercitiva. Aliás, a fundação e a instituição do direito jamais são momentos inscritos no âmago de uma homogeneidade empírica de uma história, pois estes momentos rasgam o próprio tecido da história com uma decisão (Derrida, 2010).

Portanto, a operação de fundar e justificar o direito, de estabelecer o direito, consiste em um discurso portador de uma violência performativa e interpretativa que em si mesma não é justa, nem injusta. Mas o próprio discurso, segundo Derrida (2010), encontra ali mesmo o seu limite. Há aí um nexo e um silencio murado e emparedado - porque não é exterior à linguagem - na estrutura mítica e violenta do ato fundador.

A autoridade da lei só pode apoiar-se em si mesma e, sob este aspecto, o direito implica uma violência sem fundamento prévio metalinguístico.

Nesta perspectiva de Derrida, o direito fundado está sempre sujeito à desconstrução porque ele é histórico e seu fundamento é sempre mítico. Assim, a desconstrução encontra a sua força de inspiração e a sua motivação no próprio apelo sempre insatisfeito, para além das determinações dadas em que se inscreve a justiça enquanto direito em sua concretude histórica.O entendimento de que o direito é jamais a realização plena da justiça no mundo alimenta a exigência ativa e interminável de que o direito se torne sempre mais justo. É nestes termos que o autor chega a identificar desconstrução e justiça.

Não obstante, a justiça pretende realizar-se no mundo, o que exige que sejam tomadas decisões consideradas justas, mesmo sabendo que isso é integralmente impossível, pois a justiça é incalculável e, portanto, indecidível. Nesta perspectiva,

${ }^{10}$ DERRIDA, 2010; p.24-25. 
contudo, o decidir éinexorável e inescapável porque sem uma decisão, nenhuma justiça afirmar-se-á de modo positivo e efetivo na forma do direito.

Todavia, sob este prisma, "uma indecidibilidade essencial aloja-se em cada decisão como um fantasma que desconstrói do interior toda e qualquer segurança de presença, toda a certeza ou toda a pretensa criteriologia que nos asseguraria a justiça de uma decisão"(Derrida, apud Araújo Costa, 2009, p.6).

Ainda cabe destacar o seguinte sobre a origem da autoridade e a fundação da lei, segundo Derrida:

\footnotetext{
Elas excedem a oposição do fundado ao não fundado, como de todo fundacionismo ou todo antifundacionismo. Mesmo que o êxito de performativos fundadores de um direito (por exemplo, de um Estado como garante de direito) suponha condições e convenções prévias (por exemplo, no espaço nacional ou internacional), o mesmo limite "místico" ressurgirá na origem suposta das ditas condições, regras ou convenções - e de sua interpretação dominante. ${ }^{11}$
}

Por outro lado, em relação aos temas da ética e da política, a posição de Derrida nos faz ver que muitos dos princípios a que a tradição ocidental atribuiu validade universal não comportam um efetivo partilhar. Pois, antes eles impõem um conjunto de padronizações que, dependendo do contexto, favorecem somente alguns grupos de indivíduos e trazem prejuízo para os demais.

Entretanto, a abordagem de Derrida sobre a ética e a política tem outra dimensão por ele considerada muito relevante: "ele chama-a de responsabilidade diante da alteridade e da diferença, aquilo que está além das fronteiras da descrição, do excluído e do silencioso. Esse senso de responsabilidade expressa a demanda por universalismo que está associada ao lluminismo" (Derrida, apud, Borradori, 2004, p.27).

Sob outro ângulo de seu approach da ética e da política, Derrida analisa criticamente a noção de tolerância. A propósito, segundo Borradori:

Derrida enfatiza a matriz marcadamente cristã da noção de tolerância, o que a torna um conceito político e ético menos neutro do que pretende ser. A origem religiosa e o foco da noção de tolerância fazem dela o remanescente de um gesto paternalista em que o outro não é aceito como um parceiro igual, mas subordinado, talvez assimilado e certamente mal interpretado em sua diferença. ${ }^{12}$

\footnotetext{
${ }^{11}$ DERRIDA, 2010, p.26.

12 BORRADORI, 2004, p.27.
} 
Desse modo, a noção de tolerância, devido a sua implicação religiosa, com fortes raízes na caridade cristã, faz desmoronar qualquer pretensão de universalismo a respeito desta palavra. Assim, como alternativa a este termo, Derrida sugere a idéia de hospitalidade, que para ele, não envolve uma mera sutileza semântica em relação à noção de tolerância, mas aponta para algo mais importante que é: "a obrigação única que cada um de nós tem com o outro" (Borradori, 2004, p.28).

Para Derrida: "A hospitalidade pura e incondicional, a hospitalidade em si, abre-se ou está aberta previamente para alguém que não é esperado nem convidado, para (...) um visitante absolutamente estranho, como um recém-chegado, não identificável e imprevisível, em suma, totalmente outro" (Borradori, 2004, p.28).

A hospitalidade incondicional corresponde ao direito de visitação e, como tal, expõe o anfitrião ao risco máximo, pois, conforme Derrida (2004), não dá margem a qualquer defesa ou imunidade sistemática contra o outro, além de não poder ter um status jurídico ou político. Por outro lado, a hospitalidade condicional ou tolerância é fundamentalmente o direito de convite, lançando as condições para as convenções internacionais e cosmopolitas.

Segundo o filósofo franco-argelino:

Os estados não podem incluir [a hospitalidade incondicional] em suas leis, porque a hospitalidade sem condições é irreconciliável com a própria idéia de um Estado soberano [cujas leis e direito estão imbricados com a violência fundadora e conservadora]. E, no entanto, é somente do ponto de vista da hospitalidade incondicional, ou do direito de visitação, que conquistamos uma perspectiva crítica dos limites do direito cosmopolita, de tolerância, hospitalidade condicional e direito de convite. ${ }^{13}$

Ademais, os ideais da democracia e da justiça não se coadunam com o cosmopolitismo, com a cidadania mundial e com a economia de soberania política e jurídica. Conforme Derrida:

O cosmopolitismo aplica-se a um mundo visto como um cosmo que desde os gregos significa um todo bem-ordenado regulado por princípios e leis. Embora Derrida explicitamente aceite o cosmopolitismo e a cidadania mundial, ele sente que o compromisso com a justiça não pode ser plenamente exercido dentro das fronteiras da lei e do cosmopolitismo. Pois a justiça, assim como a democracia, não tem a ver apenas com a nossa

${ }^{13}$ DERRIDA 2004, p.171. 
conduta dentro da moldura do Estado ou sob as obrigações da cidadania, mas também em face de um estranho. ${ }^{14}$

De acordo com a crença de Derrida (2004), é preciso deixar espaço para algo localizado em algum lugar além da política e da lei, do cosmopolitismo e da cidadania mundial. E esta crença está ancorada em um esquema formal: a distinção entre os registros condicional e incondicional. Enfim, segundo Derrida:

O formalismo conceitual desse gesto permite-lhe evitar ressurreições reacionárias e nostálgicas, bem como uma leitura essencialista da tradição e da identidade. A qualidade do que está além da política e da lei nunca é determinada em termos de qualquer conteúdo ou valor específico, mas simplesmente indicada como a condição de possibilidade para o que for elaborado pela política e pela lei. ${ }^{15}$

Enfim, na perspectiva derridiana, lei e justiça estão em duas dimensões diferentes, sendo que a justiça está além da lei. Ou seja, para o autor:

Como a lei é o produto da dinâmica social e política, ela é finita, relativa e historicamente determinada. Em contraste, a justiça transcende a esfera da negociação social e da deliberação política, o que a torna infinita e absoluta. A justiça, para Derrida, está além das fronteiras da política, tal como a sua inexaurível demanda. ${ }^{16}$

Sob este prisma, Derrida observa que a expressão inglesa "toenforcethe Law", que significa "impor a lei", revela a suposição decisiva em relação à natureza da lei, demarcando o uso autorizado da força. Sob este prisma como escreve o autor:

Em uma democracia constitucional a lei é autorizada porque representa a vontade dos cidadãos. No caso de um sistema político não-democrático, a autorização corresponde à autoridade incontestável de um chefe absoluto ou de um partido no poder. No entanto, em ambos os casos, o elo entre imposição e lei permite a distinção entre lei como força autorizada e violência como força não-autorizada. ${ }^{17}$

Nas palavras de Derrida, não há dúvida de que a fundação de qualquer novo estado e de suas novas leis apresenta recorrentemente um entrelaçamento inexorável com a violência. A propósito, como destaca o autor:

Todas as situações (...) e discursos revolucionários, à esquerda ou à direita, (...) justificam o recurso à violência alegando a fundação, em progresso ou

\footnotetext{
14 DERRIDA, 2004, p.172.

15 Idem, ibidem, p.172.

16 Idem, ibidem, p.173.

17 Idem, ibidem, p.173.
} 
por vir, de uma nova lei. Como a lei por vir virá por sua vez legitimar retrospectivamente a violência que possa ofender o sentimento de justiça, seu futuro anterior já a justifica. A fundação de todos os estados ocorre em uma situação que podemos assim chamar de revolucionária. Ela inaugura uma nova lei e sempre faz isso com violência. Sempre, vale dizer, mesmo quando não houve aqueles genocídios espetaculares, expulsões ou deportações que tão freqüentemente acompanham a fundação de estados, grandes e pequenos, velhos ou novos, próximos de nós ou distantes (...). Esses momentos, supondo que os possamos isolar, são aterrorizantes, [não só] por causa dos sofrimentos, dos crimes e das torturas que raramente deixam de acompanhá-los, mas também porque são, em si e em sua própria violência, [avessos à interpretação] ou indecifráveis. ${ }^{18}$

Ainda referente ao pensamento de Derrida, cabe aqui destacar uma pertinente observação de Zizek:

Talvez encontremos a formulação filosófica última da oposição entre política/polícia [e também entre justiça e direito] em Derrida, que opõe ontologia e hantologia (hanter=assombrar), na lógica impossível da espectralidade que sempre impede/difere/desloca o fecho do edifício ontológico: o verdadeiro gesto desconstrucionista consiste em manter a abertura espectral e resistir à tentação do seu fecho ontológico Zizek. ${ }^{19}$

Enfim, para Derrida, qualquer direito fundador não consegue nem garantir, nem invalidar a legalidade e legitimidade das leis, o que nos possibilita desconstruir o direito, de modo que a própria desconstrução é identificada com a justiça.

\section{Reflexões sobre a lei, o poder, a violência e o ato político, conforme Slavoj Zizek}

Slavoj Zizek (2009b) chama a atenção para as dimensões simbólica, objetiva (sistêmica) esubjetiva da violência. Mas, além disso, ele ainda observa que referente à questão da violência da lei e do poder - também não se pode desconhecer a novidade radical,para a abordagem de tal problemática, contida na concepção kantiana da Lei moral (Zizek, 2009a).

Segundo Zizek (2009a), a lei kantiana não é uma simples forma vazia que se aplicaria a um conteúdo empírico a fim de assegurar que esse conteúdo encontre os critérios de adequação ética.

A forma vazia da Lei funciona antes como a promessa de um conteúdo ausente que nunca está por vir. Essa forma não é o molde neutro-universal da pluralidade dos diferentes conteúdos empíricos, mas atesta o fato de uma incerteza persistente quanto ao conteúdo dos nossos atos. Ou seja, nunca sabemos se o

\footnotetext{
${ }^{18}$ DERRIDA, 2004, p.174.

${ }^{19}$ ZIZEK, 2009a, p.240.
} 
conteúdo determinado, que presta contas da especificidade de nossos atos, será o correto, ou seja, nunca sabemos se agimos efetivamente de acordo com a Lei e não fomos guiados por ocultas motivações patológicas (Zizek, 2009a).

Enfim, segundo Zizek:

\begin{abstract}
Kant anuncia assim a noção de Lei que encontra seu ponto culminante em Kafka e na experiência do moderno "totalitarismo" político: visto que no caso da Lei, o seu Dass-Sein (o fato da Lei) precede o seu Was-Sein (o que é essa Lei), o sujeito encontra-se numa situação em que, apesar de saber que existe uma Lei, ele nunca sabe (e a priori, nunca pode saber) o que é essa Lei - [pois há] uma distância exata que separa sempre a Lei das suas encarnações positivas.Por conseguinte, o sujeito é, a priori, na sua própria existência culpado: culpado, sem sequersaber de quê (e culpado por isso mesmo), [quando está] infringindo a lei sem sequer conhecer assuas regulações exatas. Segundo Zizek, o que temos aqui, e pela primeira vez na história da filosofia, é a afirmação da Lei como inconsciente: a experiência da Forma sem conteúdo é sempre indício de um conteúdo recalcado, ou seja, quanto maior for a intensidade com que o sujeito adere à forma vazia, mais traumático se torna o conteúdo recalcado. ${ }^{20}$
\end{abstract}

Assim, essa ausência da Lei - enquanto um conjunto determinado de normas positivas universais - torna ainda mais forte a pressão insuportável que a Lei moral exerce como pura injunção vazia para que cada um cumpra o seu Dever. Assim, (...) é aqui que encontramos a distinção crucial entre as regras a inventar e a Lei/Interdito que as apóia (Zizek, 2009a, p.363).

Portanto, quando a Lei falha em apresentar-se "como conjunto de normas universais simbólicas é que a encontramos na sua forma mais radical, a Lei sob o aspecto do Real de uma injunção incondicional” (Zizek, 2009a, p.363).

Desse modo, segundo Zizek:

\begin{abstract}
Se lermos Kant em termos psicanalíticos, a distância entre as regras que inventamos e a Lei que as sustém não é senão a distância entre regras (conscientemente pré-conscientes) que seguimos e a Lei como inconsciente: a lição básica da psicanálise é que, na sua forma mais radical, o Inconsciente não é a multiplicidade dos desejos ilícitos "reprimidos", mas a própria Lei fundamental. ${ }^{21}$
\end{abstract}

Sob este aspecto, mesmo um sujeito bastante narcísico é apoiado, em termos de seu uso dos prazeres, "pela injunção incondicional inconsciente de um superego que lhe ordena que goze" (Zizek, 2009a, p.363).

Por conseguinte, o sujeito,quando infringe a lei sem conhecer efetivamente as determinações dessa lei, sente-se culpado, ou seja, sofre uma recriminação interna

\footnotetext{
${ }^{20}$ ZIZEK 2009a, p.362.

${ }^{21}$ Idem, ibidem, p.363.
} 
que Ihe traz um forte mal-estar. Em decorrência disso, segundo Zizek (2008), é preciso que se estabeleça uma cisão entre a Lei pública e seu complemento superegóico obsceno, pois, é isso que nos faz confrontar o próprio âmago da paralaxe político-ideológica:

\begin{abstract}
A lei pública e seu complemento superegóico não são duas partes diferentes do edifício legal, são o mesmo e o único "conteúdo" - com uma pequena mudança de ponto de vista, a Lei digna e impessoal assemelha-se a uma máquina obscena de jouissance (gozo). [E com] outra leve mudança e [o que ocorre é que] as regulações legais, que prescrevem nossos deveres e garantem nossos direitos, parecem ser a expressão de um poder impiedoso cuja mensagem a nós, súditos, é: "Posso fazer o que quiser com vocês!". ${ }^{22}$
\end{abstract}

Segundo Zizek, o mestre inimitável dessa mudança paraláctica em relação ao edifício do poder legal foi Kafka, pois foi ele que primeiro percebeu "(...) uma máquina gigantesca de jouissance [de mais-gozar obsceno] no que antes parecia um digno edifício da Ordem legal” (Zizek, 2008, p.438).

De outro ângulo, ainda no que se refere à questão da violência, cabe observar que, conforme Zizek (2009b), ela emerge do campo simbólico da linguagem; da dimensãoobjetiva (ou sistêmica) de base estrutural e histórico-social; e da própria subjetividade humana. A partir desta complexa multiplicidade paraláctica de pontos de incidência, Zizek aborda a noção de violência a partir destas três dimensões cruciais.

Primeiro temos, segundo o autor (2009b), uma violência simbólica que é o tipo mais decisivo e fundamental de violência. Esta dimensão da violência encarna a linguagem e suas formas, desde o cerne do registro simbólico. E, como tal, ela envolve os significantes mestres e os significantes do saber, que se exprimem via sujeito da enunciação inconsciente, os quais, porém, incidem sobre a conformação de um determinado universo de significado que, ademais, é socialmente construído e, sob este aspecto, relacionado ao sujeito do enunciado. A violência simbólica, exercida pela classe dominante - mediante o um discurso de controle ideológicohegemônico sobre as relações sociais de produção e sobre o conjunto da reprodução social -, impacta sobre a identidade das classes e frações da classe dominadas e exploradas. Da mesma forma, segundo Zizek (2009b), o discurso racista, de que os negros são inferiores aos brancos, afeta e cerceia a identidade sócio-simbólica dos negros, tornando os negros realmente inferiores na sociedade,

${ }^{22}$ ZIZEK, 2008, pp. 437-438. 
de modo que a violência exercida mediante a linguagem é efetiva e eficiente. Enfim, aviolência simbólica que se articula a partir das próprias estruturas da linguagem, além de incidir sobre as práticas econômicas de reprodução social, funciona, portanto, também como dispositivo ideológico discursivo extra-econômico que costura e amarra a reprodução sócio-cultural e sócio-política na sociedade capitalista. Esta função extra-econômica exercida mediante diversos dispositivos de violência simbólica é algo indispensável à dinâmica contemporânea do capitalismo globalizado, pois este não conseguiria completar o seu ciclo de reprodução social, sem o apoio em dispositivos normativos, burocrático-institucionais, midiáticos, tecnológicos de controle e ideológico políticos e culturais.

Uma segunda dimensão da violência, segundo Zizek (2009b), se configura como violência objetiva ou sistêmica, que aparentemente é menos visível, mas que é crucial para se captar criticamente a complexa articulação com as demais formas ou dimensões da violência. Estaforma de violência é inerente ao que imaginariamente é percebido como estado normal e pacífico das coisas. A propósito, a violência objetiva deve ser compreendida a partir de um lastro estrutural e histórico. Ela é relacionada às próprias coordenadas sistêmicas da ordem social capitalista da contemporaneidade e à dinâmica histórica do capital. O fetichismo da mercadoria e da mercadoria-imagem, o valor de troca e a lei do valor que conformam o mercado capitalista e que incidem sobre as práticas sociais cotidianas, igualmente são aspectos da violência sistêmica.

As coordenadas sistêmicas apresentam ainda uma outra dimensionalidade estrutural oculta, anônima e inconsciente de antagonismo social, articulada desde o cerne de um núcleo contraditório fundamental que é a "luta de classes". Esta divisão social fundamental exerce uma força constritora sobre todas as diferenças sociais, étnicas, raciais, de gênero, religiosas e culturais. Enfim, este cerne funciona com uma divisão social e política estrutural anônima, que superdetermina o arranjo dinâmico das relações de exploração e dominação social e as relações de força política na sociedade.

Uma terceira dimensão da violência, visualizada por Zizek (2009b), é a violência subjetiva, que é a mais visível das formas de violência. Mas ela é visualizada de forma equívoca quando não abordada a partir da articulação complexa que a envolve com as demais dimensões da violência, quais sejam, a simbólica e a objetiva (ou sistêmica). O elemento que a caracterizaé o fato de ela se 
exprimir mediante os atos de determinados agentes sociais explicitamente identificáveis, que perturbam o aparente estado normal e pacífico das coisas no contexto sócio-político da sociedade.

Desse modo, segundo Zizek (2009b), a violência subjetiva se articula em torno de práticas sociais autoritárias(ou agressivas) fundamentalistas,envolvendo turbas fanáticas. Ademais, ela também pode se configurar a partir de agentes sociais engajados em aparelhos repressivos disciplinados, ou a partir de associações privadas legais e ilegais que espalham ações violentas recobertas de terror e medo. Ela pode, igualmente, emergir como atos violentos com motivações criminosas, perpetrados por indivíduos malévolos. Enfim, ela pode também brotar enquanto atos isolados de violência, com traços de anormalidade ou patológicos; ou, mesmo, enquanto práticas reativas de ressentimento e de desespero social, sem nenhuma visualização alternativa ou revolucionária de sociedade. Enfim, é fundamental que não se visualize a violência subjetiva como um fetiche. Ao contrário, a tarefa central é compreender a complexa interação das três dimensões da violência: a subjetiva, a objetiva e a simbólica.

O capitalismo globalizado contemporâneo, para fazer frente à sua crise de legitimidade e de acumulação ampliada, necessita recorrer a sutis e sofisticadas formas complementares de dominação político-social, para manter em movimentação acelerada a dinâmica dos fluxos do mercado. $\mathrm{E}$, em um quadro de afirmação do paradigma tecnológico da automação e da digitalização, acompanhado por práticas de gestão flexíveis e fragmentárias, um dos recursos adotados é o consumismo artificialmente induzido a crédito sob a emulação do reino da mercadoria-imagem, da propaganda, do marketing e da marca dos produtos. Enfim, as práticas sociais capitalistas ostentam o fetichismo da mercadoria imagem e a lei do valor como seu núcleo articulador e dinamizador. Portanto, mecanismos extraeconômicos de controle, sedução, alienação e de absorção funcionam como elementos de captura da subjetividade dos indivíduos.

A propósito, uma ampla variedade de dispositivos e de produtos tecnológicos de consumo - centrados nos chamados gadgets ou engenhocas eletrônicas e digitais - alimenta as formas variadas de "prazeres menores" e de gozo fatiado e fragmentário (ou "pedaços de gozo") experimentadas pelos indivíduos na sociedade de consumo e de espetáculo contemporânea. 
De outro lado, ainda sob este prisma, segundo Zizek (2009b), cabe enfatizar a proliferação de formas pós-políticas e biopolíticas de controle social que se articulam em torno da gestão do medo. Nestas circunstâncias, o próprio Estado concentra as suas forças, prioritariamente para garantir o livre fluxo das mercadorias materiais (e imateriais) no mercado. Assim, as políticas públicas e sociais voltadas para o bemestar, a segurança e a dignidade dos cidadãos tornam-se cada vez mais limitadas e desintegradas, sendo progressivamente substituídas por "biopolíticas" pós-políticas de administração da "vida nua".

Desde o cerne desta perspectiva, as relações sociais ficam mais e mais assimétricas, desiguais e opacas, além de esvaziadas de qualquer compromisso ético e de solidariedade. Assim, a própria linguagem fica mais intensamente impregnada pela violência. Ou seja, as pessoas podem conviver socialmente, lado a lado, a partir de perspectivas bem diferentes, manifestando a maior indiferença umas com as outras, permitindo-Ihes, ademais, reproduzir sutilmente, mediante 0 próprio discurso ideológico da tolerância sócio-cultural, práticas veladas de preconceito e de segregação social.

Além disso, segundo Zizek (2009b), no universo da pós-política contemporânea, importantes categorias políticas e sociológicas, como exploração, dominação, marginalização social e desigualdade se tornam cada vez mais recalcadas. Ou seja, isto ocorre, enfim, porque o discurso ideológico dominante passa a se articular em torno da noção de tolerância. Assim, no cerne do processo de culturalização fragmentadora da política contemporânea, a polarização antagônica fundamental que é a luta de classes vem a ser substituída pelo discurso ideológico das diferenças culturais.

Por outro lado, no que tange ao conceito de universalidade, Zizek (2009b), entende que este somente passa a adquirir sua eficácia simbólica ou a sua verdadeira efetividade quando ele irrompe como dimensão universal do próprio cerne de uma realidade particular, que se experimenta como universal. A propósito, segundo Zizek (2009b, p.138): "Na luta pela emancipação, não são as culturas nas suas identidades que se dão as mãos, [mas]são as partes recalcadas, exploradas, condenadas ao sofrimento, as partes de parte nenhuma de cada cultura que se juntam numa luta partilhada".

Finalmente, ainda no que se refere ao conceito de violência divina de Walter Benjamin, esta concepção, segundo Zizek (2009b), tem um sentido oposto ao da 
violência mítica, a qual funciona como meio para afirmar o Poder e o governo da lei. Sob esta perspectiva, a violência divina é um domínio exterior ao poder legal instituído, de modo a funcionar como um excesso pulsional de morte e vida que se manifesta na história. Ou seja, a violência divina corresponde às intrusões explosivas de uma justiça para além da lei mítica e, como tal, ela não serve como meio para restabelecer o equilíbrio da justiça, mediante a punição dos culpados. Ela antes é o signo que denuncia a injustiça em um mundo eticamente desarticulado. Portanto, o lugar da violência divina é o dos extratos sociais longamente violentados simbólica, objetiva e subjetivamente. Enfim, em seu excesso vital, a violência divina - carregada de expectativas de liberdade e de emancipação - rompe a contrapelo da obscenidade de outro excesso eivado de conseqüências catastróficas, que é o do poder dominante.

Ainda, de outro ângulo, Zizek (2009b), aponta para a ambigüidade da Lei, destacando que, se no nível positivo do direito ela se encontra entrelaçada e comprometida com o poder do Estado, de outro lado, ao nível do inconsciente psíquico, ela emergeainda sob outra faceta, na forma deinterdito inconsciente incondicional.

Sob este último prisma, segundo Zizek:

[A lei se situa] ao nível subterrâneo do superego, [no qual] a mensagem
pública de responsabilidade desdobra-se na mensagem obscena do
exercício incondicional do poder: as leis não me atam de fato, pois eu posso
fazer-vos o que quero; tratar-vos como culpados se assim decidir; destruir-
vos com uma só palavra... Este excesso obsceno é um elemento
constitutivo necessário à noção de soberania. A assimetria é aqui estrutural,
ou seja, a lei não pode manter a sua autoridade se os sujeitos aí não
ouvirem o eco da auto-asserção obscena incondicional. E a violência divina
do povo é correlativa deste excesso de poder. Ela é a contrapartida deste,
dirigida completamente contra ele visando miná-lo. ${ }^{23}$

Por outro lado, Zizek coloca a necessidade de que se instaure a emergência do autêntico ato político para que se concretize uma efetiva ruptura com as coordenadas da ordem social violenta e injusta.

A propósito, segundo Zizek, o ato político somente pode ocorrer no momento em que o pensamento e a ação do sujeito se desprendem das coordenadas da rede simbólica alienante, e se atam à atividade coletiva, traduzindo-se em uma ação política soberana, sem fixação institucional imediata à intervenção política. Assim, o ato político instaura sua própria legalidade, suspendendo a Lei do poder opressor

\footnotetext{
${ }^{23}$ ZIZEK, 2009c, p.143.
} 
imperante, abrindo desta maneira espaços para a instauração de um processo de emancipação econômico-social, cultural e política.

Esta leitura de Zizek a respeito do ato políticonão encarna, a princípio, nenhuma substância positiva inicial. Ela, parte, antes da irredutibilidade negativa do inconsciente que no sujeito se define por resistir aos processos de identidade e de auto-reflexão. Portanto, este prisma analítico, se ancora no tema do descentramento do sujeito do inconsciente. "Descentramento, que indica a posição de não-identidade que um conceito não substancial de sujeito sempre sustentará diante dos espaços de representação, de auto-apreensão reflexiva e de identificação social" (Zizek, apud Safatle, 2003, p.182).

Nesta perspectiva, para Zizek, o sujeito denota uma partícula de liberdade, de modo que ele é intrinsecamente político, se encontrando em uma situação sempre aberta de inadequação e de superação. Em outras palavras: "O sujeito é aquilo que nunca é totalmente idêntico a seus papéis e identificações sociais" (Safatle, 2003, p.183).

Sob este ângulo, as políticas de identidade acabam também fazendo o jogo da ideologia e, por conseguinte, do capital. Pois, o capital acomoda-se muito bem às políticas de identidade e à multiplicidade de identidades. Sob este aspecto, a negatividade, na forma de uma universalidade não substancial e na forma de nãoadequação pode contrapor-se à falsidade da universalização da política da identidade. Sob este prisma: "A verdadeira escolha livre é aquela na qual eu não escolho apenas entre duas ou mais opções no interior de um conjunto prévio de coordenadas, mas escolho mudar o próprio conjunto de coordenadas" (Zizek, apud Safatle, 2003, p.185).

Assim, o ato político rima com uma violência redentora bejaminiana, contraposta à violência instituída na forma de repressão velada ou explícita:

Há um abismo entre o 'fundamentalismo' religioso [ou político] fanático e a intervenção revolucionária autêntica, ainda que ambos pareçam compartilhar um caráter radical. Esse abismo não se refere apenas à dimensão sóciopolítica, mas também à estrutura imanente do ato: o ato fundamentalista é realizado para o [gozo] do 'grande Outro'; nele o sujeito instrumentaliza-se [e imola-se] para o 'Outro'. [Já o ato político], como um ato autêntico se autoriza apenas em si - ou seja, ele não é coberto pelo 'grande Outro'; pelo contrário, intervém no ponto exato da inconsistência [deste último]. Essa distinção é a diferença [entre a falsa pureza do supereu obsceno e a pureza ética autêntica], entre Kant e Sade: Sade não é simplesmente a verdade de Kant; a 
posição perversa sadiana emerge, em vez disso, quando a postura ética kantiana radical está comprometida. ${ }^{24}$

Enfim, sob este enfoque, todo ato político revolucionário é incondicional. Mas, não se trata de um "ato incondicional" situado fora da história e fora do simbólico, mas simplesmente de um ato surpreendente que é irredutível ao parâmetro e à moldura das condições dadas. Como destaca Zizek:

[O] ato não só está enraizado em suas condições contingentes, como são essas mesmas condições que fazem dele um ato: o mesmo gesto, realizado num momento errado - cedo ou tarde demais -, [deixa de ser, ou] não é mais um ato. Aqui o paradoxo propriamente dialético é que aquilo que torna o ato "incondicional" é sua própria contingência: se o ato foi necessário, isso significa que foi totalmente determinado pelas condições, e pode ser deduzido a partir delas (...). O vínculo entre a situação e o ato político, portanto, é claro: longe de ser determinado pela situação (...), o ato é possível em razão do não fechamento ontológico, (...) das lacunas de uma situação. ${ }^{25}$

Portanto, no ato de liberdade e de emancipação o agente revolucionário não pede permissão ou não fica refém a alguma imagem ou ao gozo capturador e mortífero do "grande Outro". Ademais, o ato político revolucionário não pede permissão a nenhum Outro disfarçado de legitimação/autorização liberaldemocrática de nossos atos, ao contrário, o ato se autoriza por si mesmo com base em sua própria Causa.

\section{A título de fechamento do texto: uma conexão com a educação}

Para Benjamin, tudo indica que a violência é um conceito que pertence à ordem simbólica da lei, da política e da moral. E, ao partir desta premissa, o filósofo judeu-alemão não distingue entre força autorizada e não-autorizada da lei, mas entre "força fazedora-da-lei", que se refere ao momento de fundação do sistema legal, e "força conservadora-da-lei", que corresponde à imposição da lei.

Portanto, para Benjamin, a violência (Gewalt), presente na instauração e na manutenção do direito, é justificada como um meio não apenas para a fundação, mas também para a legitimação e a aplicação do direito, no cerne da estrutura do poder. Assim, pois, o direito e o poder jamais abdicam da violência como ameaça latente permanente. Ou seja, a própria fundação do direito constitui a violência como sua força instauradora eela, a violência, é mantida como ameaça no exercício de sua aplicação.

\footnotetext{
${ }^{24}$ ZIZEK, 2005, p.261.

${ }^{25}$ ZIZEK, 2011 a, p.311.
} 
Como contraponto radical à violência mítica, que acompanha qualquer poder soberano, Benjamin ressalta a força redentora da "violência divina". Portanto, ele acredita na possibilidade de uma violência divina pura, fora do direito e não proveniente de uma decisão da vontade do poder, mas originária de uma ação humana anônima.

Sob este aspecto, a violência divina apresenta uma forte afinidade com o ato revolucionário que rompe com o status quo. Enfim,que rompe com o estado de exceção do poder soberano, na medida em que se encontra atravessada por uma determinada idéia de justiça, sem mediações com o poder constituído.

Movido por uma criativa inspiração libertária e de justiça social, Benjamin também fez acerbadas críticas às concepções racionalistas sobre a infância e a educação e atribuiu uma importância decisiva à memória dos sujeitos. Sob este prisma, ele apresenta um olhar crítico ao significado tecnicista-instrumental, utilitarista e pragmático que a educação adquiriu na modernidade tardia.

Para o filósofo alemão, a criança e o educando, assim como o autêntico educador, são movidos por uma vocação e um potencial de criatividade e de abertura originária, enquanto inseridos em uma cultura e em uma conformação histórica específica. Enfim, para Benjamin, a infância e a educação, a partir de uma perspectiva de liberdade e emancipação, implicam a suspensão do tempo linear e vazio e convocam o tempo intensivo e surpreendente do 'agora' (Jetztzeit). Tempo este que se exprime por gestos de redenção das experiências fracassadas do passado à luz do presente.

Por outro lado, retomando aqui o foco sobre as leituras de Derrida, cabe observar que, segundo este autor,a origem da autoridade, a fundação e a posição da lei não podem por definição repousar em nada além de si mesmas.Ou seja, para Derrida a fundação de uma nova formatação de leis ocorre na ausência de qualquer padrão legal, o que a torna explicitamente ilegal. Nessa medida, Derrida acha que a justificação moral da lei, isto é, a justiça, está sempre por vir, ou seja, desse modo, a justiça adquire uma "futuridade irreversível". Sob este prisma, a legitimidade de uma conformação legal não pode ocorrer a não ser retroativamente, ou seja, a partir do momento em que o sistema de lei tenha sido estabelecido e, então, puder ser imposto.

Ademais, tanto a teoria política de Derrida como as suas reflexões sobre qualquer concepção educacional voltada para a liberdade e a emancipação implicam 
uma lacuna irredutível. Lacuna esta que se estabelece entre a promessa de uma democracia e de uma perspectivaeducacional de emancipação plena sempre por vir, mas que jamais se concretizarão de modo pleno, e uma variedade de políticaseconômico-sociais determinadas e contingentes e práticas educacionais concretas que sempre contém falhas, contradições e problemas. A propósito, como escreve Zizek (2013, p.110), a respeito da "radicalidade" da política derridiana: "A discrepância entre o abismo da Coisa indecidível e qualquer decisão particular é irredutível".

Sob este prisma, tanto a política como a educação trazem embutida a questão da ética como pano de fundo da indecidibilidade. Em determinadas situações - no domínio do político e do educacional enquanto esferas de decisões e de práticas -, os agentes políticos e educacionais aceitem o desafio ea responsabilidade de assumir o risco de cruzar o abismo e estabelecer intervenções particulares e concretas em relação às quais há grandes expectativas. Mas elas jamais estarão à altura da promessa e do pedido ético incondicional (e espectral) por emancipação e justiça plena. Pois, toda e qualquer decisão positiva estará sempre marcada pela temporariedade epela contingência. Ou seja, ela traz embutida, de modo inerente, uma diferença indefinida que, em última instância, leva as políticas econômico-sociais e culturais e as práticas educacionais implantadas a um fracasso, de modo que prevalece aí um hiato intransponível frente ao pedido ético incondicional. Contudo, esta lacuna também sempre impede o fecho do edifício ontológico, de maneira que o verdadeiro gesto desconstrucionista não só consiste em manter a abertura espectral e transcendental que impede o fecho ontológico, mas exige novas reconstruções, após as demolições desconstrucionistas (Zizek, 2009a).

Enfim, a desconstrução sempre implica um novo gesto de afirmação reconstrutiva, ou seja, um sim originário, que não é movido pelo dogmatismo e nem pelo consentimento cego e positivista, mas pelo compromisso de aceitar uma herança, de relançá-la de outro modo, com o propósito de mantê-la viva (Scliar, 2005).

Sob este prisma da filosofia de Derrida, também, qualquer prática educacional voltada de alguma forma para a perspectiva da liberdade e afirmação da singularidade humana, terá que estar compromissada com a tarefa de desarticular e 
"desfazer a metafísica da presença, da identidade do ser e/ou donão-ser (...)" (Scliar, 2005, p.20).

A propósito, segundo o approach do filósofo franco-argelino, a política e a educação só podem ser um acontecimento ou um evento, caso assumam um diálogo sempre aberto com a singularidade do outro e respeitem a sua alteridade. Pois, somente desse modo, se manifesta aí uma perspectiva de desconstruçãoreconstrução atenta para a justiça sempre por vir e para uma ética responsável para com o outro e por mim mesmo - como uma identidade que é sempre atravessada pela diferença.

Por fim, referente ao pensamento de Slavoj Zizek, cabe observar que segundo este autor, uma distância exata sempre separa a lei de suas encarnações positivas. Ou seja, a idéia de uma forma vazia da lei sem conteúdo remete à afirmação da lei como inconsciente e como indício de um conteúdo recalcado.

Assim, a inexistência de um conjunto determinado de normas positivas universais torna a lei moral uma pura injunção vazia que pressiona a cada indivíduo a cumprir seu dever. Segundo Zizek (2009a), a lei/Interdito inconsciente, sobre a qual se apoia toda e qualquer regra positiva a inventar, supõe uma distinção crucial e uma distância na forma de um hiato entre o conjunto positivo de leis simbólicas universais e a Lei enquanto interdito inconsciente. Dessa maneira, como nos esclarece a psicanálise, o próprio Inconsciente, em sua forma mais radical, não é a multiplicidade dos desejos ilícitos "reprimidos", mas a própria Lei fundamental. A propósito, encontramos este interdito inconsciente como o Real de uma injunção incondicional, sempre quando a Lei falha em apresentar-se como conjunto positivo de normas universais simbólicas.

Em decorrência disso, segundo Zizek (2008), é preciso que se estabeleça uma cisão entre a Lei pública e seu complemento superegóico obsceno, pois, é isso que nos faz confrontar o próprio âmago da paralaxe político-ideológica. Contudo, estas duas dimensões da lei não são duas partes diferentes do edifício legal, pois elas são o mesmo e o único "conteúdo". Ou seja, com um pequeno deslocamento de ponto de vista, a Lei digna e impessoal assemelha-se a uma máquina obscena de jouissance (gozo).

Por sua vez, a violência apresenta, para Zizek (2009b), três dimensões - a simbólica, a objetiva (ou sistêmica) e a subjetiva - que apenas sob o prisma de um corte epistemológico e analítico podem ser abordadas de modo separado. 
As dimensões mais cruciais e decisivas da violência são a simbólica - que é relacionada à estrutura da linguagem - e a sistêmica, que se estrutura a partir das coordenadas sistêmicas e histórico-sociais, que pré-definem o leque de escolhas econômicas, políticas e culturais disponíveis aos sujeitos. Por fim, temos a violência subjetiva, que é aquela que aparece de modo explícito, mas que não pode ser abordada de modo consequente sem sua inter-relação com duas outras, a simbólica e a sistêmica.

Por outro lado, referente à educação, Zizek (2013) ressalta que esta, cada vez mais, está mergulhada em uma profunda crise. Pois, o seu papel institucional relacionado à socialização e à produção e reprodução de conhecimentos, tende a se restringirprioritariamente à oferta de uma aprendizagem de habilidades voláteis voltadas para o exercício de tarefas flexíveis ligadas a ocupações específicas, demandadas pelo mercado de trabalho. Assim, a educação passa a adequar-se integralmente ao status quo, ao mesmo tempo em que a idéia de uma cultura educacional qualificada e universal passa a ser completamente abandonada.

Ademais, conforme Zizek (2013), as gerações de professores - que no passado eram verdadeiros pensadores e debatedores públicos dos problemas econômico-sociais, políticos e culturais - praticamente desapareceram. Estes professores foramsubstituídos por acadêmicos reclusos e apáticos, cuja atividade não envolve nenhum engajamento político efetivo, fora dos muros dos espaços acadêmicos. Ademais, seus discursos, além de estarem impregnados de jargões elitistas, estão embriagados por uma reflexividade racionalista reprodutora do sempre mesmo. De modo que, a própria educação superior universitária perdeu o seu elo de conexão com abordagem crítica das contradições e das catástrofes sociais que afetam a maioria da população mundial, no cerne do capitalismo global contemporâneo.

Enfim, no atual contexto, segundo Zizek (2011), a educação privatizada e flexível substituiu em larga medida a educação pública e universal. O mercado invadiu a educação que antes era considerado domínio privilegiado do estado. E neste quadro - as práticas educacionais não correspondem mais aos interesses, às necessidades e às aspirações da maioria da população. Assim, cabe reinventar a educação radicalmente, pois a privatização do conhecimento intelectual e social e os processos de automação e digitalização produtivo-industrial e de serviços acompanhados pela desverticalização, flexibilização e precarização das relações de 
trabalho -, podem desempregar e/ou sub-empregar em torno de $80 \%$ da força de trabalho mundial, de modo que uma educação que se restringe a atender as demandas do mercado capitalista é uma educação em profunda crise e deslocada dos graves problemas sociais que afligem a humanidade. 


\section{BIBLIOGRAFIA}

ARAÚJO COSTA, Alexandre. Direito, Desconstrução e Justiça: reflexões sobre o texto Força de Lei, de Jacques Derrida. Publicado em dezembro de 2009. Disponível em: http://www.arcos.org.br/artigos/direito-desconstrucao-e-justiça/.

BENJAMIN, Walter. Para uma Crítica da Violência. In: GAGNEBIN, Jeanne Marie (org.), Walter Benjamin: Escritos Sobre Mito e Linguagem. São Paulo, Duas Cidades: Editora 34, 2011, pp.121-156.

BORRADORI, Giovanna. INTRODUÇÃO: Terrorismo e o legado do lluminismo, Habermas e Derrida. In: BORRADORI, Giovanna (org.) Filosofia em Tempo de Terror: Diálogos com J. Habermas e J. Derrida. Rio de Janeiro: Jorge Zahar, 2004, pp.13-34.

CALLADO, Tereza de Castro. A Lógica da Exceção na Reflexão Política de Walter Benjamin. In: CHAGAS, Eduardo \& RECH, Hildemar Luiz, et alii (orgs.), Subjetividade e Educação. Fortaleza, Edições UFC, 2012, pp.84-103.

DERRIDA, Jacques. Força de Lei: O Fundamento Místico da Autoridade. São Paulo, Editora WMF Martins Fontes, 2010.

DERRIDA, Jacques. Desconstruindo o terrorismo. In: BORRADORI, Giovanna (org.) Filosofia em Tempo de Terror: Diálogos com Jürgen Habermas e Jacques Derrida. Rio de Janeiro: Jorge Zahar Editor, 2004, pp.147-180.

SAFATLE, Vladimir. Posfácio: A Política do Real de Slavoj Zizek. In: ZIZEK, Slavoj. Bem-vindo ao Deserto do Real!: Cinco ensaios sobre o 11 de setembro e datas relacionadas. São Paulo, Boitempo Editorial, 2003, pp.179-191.

SCLIAR, Carlos. A Escrita na Escrita: Derrida \& a Educação. In: SKLIAR, Carlos (org.). Derrida \& a Educação, Belo Horizonte, Autêntica, 2005, pp.9-38.

SELIGMANN-SILVA, Márcio. Walter Benjamin: o Estado de Exceção entre o político e 0 estético. Public. $2005 . \quad$ Disponível em: www.letras.ufmg.br/cadernosbenjaminianos.

ZIZEK, Slavoj. Alguém Disse Totalitarismo?: cinco intervenções no (mau) uso de uma noção. São Paulo, Boitempo Editorial, 2013.

ZIZEK, Slavoj. O Ano em que Sonhamos Perigosamente.São Paulo, Boitempo, 2012.

ZIZEK, Slavoj. Em Defesa das Causas Perdidas. São Paulo, Boitempo, 2011a.

ZIZEK, Slavoj. Primeiro Como Tragédia, Depois Como Farsa. SP, Boitempo, $2011 b$.

ZIZEK, Slavoj. O Sujeito Incômodo: O Centro Ausente da Ontologia Política. Lisboa, Relógio D’Água Editores, 2009a. 
ZIZEK, Slavoj. Violência: Seis notas à margem. Lisboa, Relógio D’Água Ed., 2009b.

ZIZEK, Slavoj. De La démocracie à laviolencedivine. In: Democracie, das quelÉtat?, Paris, La Fabrique Ed., 2009c.

ZIZEK, Slavoj. A Visão em Paralaxe. São Paulo, Boitempo Editorial, 2008.

ZIZEK, Slavoj. Às Portas da Revolução: Seleção de Escritos de Lenin de fevereiro a outubro de 1917. São Paulo, Boitempo Editorial, 2005.

ZIZEK, Slavoj. Bem-vindo ao Deserto do Real!: Cinco ensaios sobre o 11 de setembro e datas relacionadas. São Paulo, Boitempo Editorial, 2003. 